\title{
Estimation of the potential of Lemna minor for effluent remediation in integrated multi-trophic aquaculture using newly developed synthetic aquaculture wastewater
}

\author{
Simona Paolacci ${ }^{1,2}$ (D) Vlastimil Stejskal ${ }^{1,2,3} \cdot$ Marcel A. K. Jansen $^{1,2}$ \\ Received: 21 January 2021 / Accepted: 14 June 2021/Published online: 30 June 2021 \\ (C) The Author(s) 2021
}

\begin{abstract}
Aquaculture is an important source of animal protein and a key contributor to global food security. However, aquaculture can exert a negative effect on the aquatic environment due to the release of effluents containing high nutrient levels. In integrated multi-trophic aquaculture (IMTA), the waste produced by one species is the input for another, referred to as extractive species (ES). Potential ES include plants. In the present study, it was explored whether Lemna minor can be used to remove nitrogen and phosphorus from aquaculture wastewater. A representative synthetic wastewater was designed based on the composition of aquaculture effluents found in the literature. Synthetic wastewater was found to be a suitable medium for growth of Lemna minor, and plants readily took up $\mathrm{NH}_{4}{ }^{+}-\mathrm{N}, \mathrm{NO}_{3}-\mathrm{N}$ and $\mathrm{PO}_{4}{ }^{3-}-\mathrm{P}$. In particular, $\mathrm{NH}_{4}{ }^{+}-\mathrm{N}$ concentrations rapidly decreased. The highest removal rates per square meter of water surface, calculated for $\mathrm{NH}_{4}{ }^{+}-\mathrm{N}, \mathrm{NO}_{3}{ }^{-}$ $\mathrm{N}$ and $\mathrm{PO}_{4}{ }^{3-}-\mathrm{P}$, were, respectively, 158, 206 and $32 \mathrm{mg} \cdot \mathrm{m}^{-2} \cdot$ day $^{-1}$, and these rates were achieved at a plant surface density of $80 \%$. As removal of nutrients is essentially a surface area-related process, the effect of plant density on nutrient uptake was determined. Uptake of nutrients per square meter of surface area was highest at the highest plant density. Yet, when uptake rates were calculated per square meter of water area covered by Lemna fronds, the highest removal rates were found at the lowest plant density, and this is likely to be associated with a reduced intraspecific competition. The present work enables the calculation of potential nutrient uptake by Lemna minor and lays the foundation for a more scientific approach to the design of duckweed-based aquaculture wastewater treatment systems.
\end{abstract}

Keywords Lemnaceae $\cdot$ Aquaculture $\cdot$ Water restoration $\cdot$ Removal rate $\cdot$ Synthetic wastewater

Handling Editor: Gavin Burnell

Simona Paolacci

spaolacci@bmrs.ie

Extended author information available on the last page of the article 


\section{Introduction}

Global food security refers to a scenario in which everybody has access to sufficient, safe and nutritious food (FAO 2001). Food quality is a major consideration in the concept of food security and, especially, the supply of quality protein is of concern (Tuomisto 2010). Fish in the broadest sense, i.e. including shellfish, is a key source of animal protein with some 4.5 billion people worldwide acquiring at least $15 \%$ of their intake from this source (Naylor et al. 2000). However, the stagnation in capture fisheries has resulted in a situation whereby supply is not meeting demand (Ahmed et al. 2019). This, in turn, has led to increased emphasis on fish farming to improve food security (Ahmed and Lorica 2002; Allison 2011; Jennings et al. 2016). The global production of farmed fish increased from 105.46 million tonnes in 2016 to 110.21 million tonnes in 2018 (Tacon 2018). The total global production is valued 243.26 billion of US dollars (FAO 2018). The growth of the aquaculture sector is set to continue, with the European Union having invested $€ 3.4$ billion in the aquaculture sector over the period 2000-2020 (Guillen et al. 2019).

Despite the importance of the aquaculture industry as a contributor to global food security, the sustainability of current aquaculture practises has been questioned. Negative impacts on coastal and marine habitats through, amongst others, waste disposal, fish escape and pathogen invasions have been reported (Valenti et al. 2018). Aquaculture can similarly be a major threat to the local freshwater environment (Wang et al. 2019). Effluent containing fish excrement and feed leftovers can impact on receiving waters, causing, amongst others, eutrophication and oxygen depletion (Correll 1998; Cornel and Whoriskey 1993). Regulatory authorities typically impose limits on the discharge of nutrient-rich effluents (e.g. Musacchio et al. 2020), and this necessitates some form of wastewater treatment, representing a substantial cost to the aquaculture industry (Turcios and Papenbrock 2014).

In response, integrated multi-trophic aquaculture (IMTA) has been developed. The principle of IMTA is that the waste produced by one species is the input (e.g. feed source or fertiliser) for another species, referred to as extractive species (ES). These ES include heterotrophic filter feeders and detritivores, as well as autotrophic seaweeds and a range of plant species. In essence, ES perform a form of environmental remediation. The biomass of the species used for bioremediation can comprise a second source of income for the industry (Ridler et al. 2007). As a result, IMTA systems can be mostly closed loop, with a reduced impact on the surrounding environment.

The concept of phytoremediation is well established (Chandra et al. 2017). Aquatic plant species with remediation potential are of particular interest for integration into aquaculture. Lemnaceae (common name duckweed) are a family of (mostly) free-floating freshwater plants that are known for having a high growth rate (duplication biomass in less than 2 days in optimal conditions (Ziegler et al. 2015) and high protein content (Oron et al. 1985; Mohedano et al. 2012). Moreover, ammonium, the prevalent form of nitrogen in aquaculture effluent, is the preferred form of nitrogen for Lemnaceae (Landolt and Kandeler 1987). Lemnaceae protein has the added advantage of a favourable amino acid profile, which means that biomass has potential value as a feed source (Zhou and Borisjuk 2019). The combination of remediation potential and valuable biomass makes Lemnaceae attractive candidates for the role of ES in IMTA.

In practise, a major challenge for IMTA is that a balance is needed between waste production by fish and remediation by the ES (Reid et al. 2008). Thus, it is important that the removal capacity of ES is well established, to underpin the design of IMTA systems. The 
aim of the present study was to develop a synthetic aquaculture wastewater and use it to investigate the quantitative capacity of Lemna minor to remove nutrients from aquaculture effluent. The development of the SAW is an important step to enhance reproducibility of experimental studies. This standardised synthetic wastewater facilitates generation of reproducible data that can be used to develop mathematical models on the balance between waste production and plant-based removal in IMTA. A standardised synthetic wastewater is a useful tool to test the effect of different conditions on the performance of duckweed in phytoremediation systems. For example, it can be used to verify the effect of light and temperature and to indicate the performance of these plants in different regions and/or in different seasons. Here, SAW is used to quantify the effect of nutrient availability and plant density on the removal efficiency.

\section{Material and methods}

\section{Plant material and growth conditions}

The strain of Lemna minor used for this study was collected in Blarney, Co. Cork, Ireland $\left(51^{\circ} 56^{\prime} 25.7^{\prime \prime} \mathrm{N} 8^{\circ} 33^{\prime} 49.1^{\prime \prime} \mathrm{W}\right)$ and registered in the Rutgers Duckweed Stock Cooperative (www.ruduckweed.org) as strain number 5500, also referred to as MJ100. Axenic fronds were cultured on half-strength Hutner's medium (Hutner 1953), in a growth room at a temperature of $20^{\circ} \mathrm{C}$, a light intensity of $40 \mu \mathrm{mol} \mathrm{m} \mathrm{m}^{-2} \mathrm{~s}^{-1}$ and a day/night regime of 16-h light and 8-h darkness.

\section{Synthetic aquaculture wastewater}

A synthetic aquaculture wastewater (SAW) was developed on the basis of published data. The search of peer-reviewed literature centred on studies that analysed the chemical composition of freshwater aquaculture effluents. The relevant literature was searched using the on-line scientific database Google Scholar. All searches were completed by January 2020. The principal search terms used to identify relevant publications were "freshwater, aquaculture and effluents". The first 40 search results were examined for papers providing analytical data on freshwater aquaculture effluents. Additionally, the citation lists of identified publications were inspected for further relevant papers. The papers were screened for the concentrations of $\mathrm{NO}_{3}-\mathrm{N}, \mathrm{NH}_{4}{ }^{+}-\mathrm{N}$ and $\mathrm{PO}_{4}{ }^{3-}-\mathrm{P}$ in aquaculture effluents. Variations in these nutrient concentrations were analysed in order to identify representative concentrations for SAW.

\section{Experimental design}

The nitrogen and phosphorus removal ability of L. minor in SAW was determined at four different plant densities: $20 \%\left(0.9 \mathrm{~g} \cdot \mathrm{l}^{-1}\right), 60 \%\left(1.8 \mathrm{~g} \cdot \mathrm{l}^{-1}\right), 40 \%\left(2.7 \mathrm{~g} \cdot \mathrm{l}^{-1}\right)$ and $80 \%\left(3.6 \mathrm{~g} \cdot \mathrm{l}^{-1}\right)$ of water surface area). The $100 \%$ density was not tested as, from a management point of view, it would be complicated to maintain this density at all times. In fact, growth would lead to a multi-layered mat of duckweed and cause degradation of the lower layers of duckweed and the release of nutrients in these fronds. In this paper, the plant density refers to the percentage of the surface area of the plastic culture container that was covered by fronds. The surface area of the culture containers in which the experiments were carried out was $36 \mathrm{~cm}^{2}(6 \times 6 \mathrm{~cm})$, and 
the four densities were obtained by adding fronds such that they covered, respectively, 7.2, $14.5,21.6$ and $28.8 \mathrm{~cm}^{2}$ of the available surface. These areas were covered using approximately 90, 180, 270 and $360 \mathrm{mg}$ of fresh biomass, respectively. These weights were obtained using approximately 70, 140, 210 and 280 fronds of $L$. minor. Each culture container was filled with $100 \mathrm{ml} \mathrm{SAW}$.

The experiment started with four culture containers for each plant density. Every $24 \mathrm{~h}$, one culture container per density was used to perform water analysis. The concentrations of $\mathrm{NO}_{3}$ $\mathrm{N}, \mathrm{NH}_{4}{ }^{+}-\mathrm{N}$ and $\mathrm{PO}_{4}{ }^{3-}-\mathrm{P}$ were quantified in order to determine the amount of nutrients removed. In the other culture containers, the plant density was kept constant by removing every day as many fronds as had grown during the previous $24 \mathrm{~h}$. The experiment lasted 4 days and was independently replicated twelve times. During the experiment, the plants were kept under the same growth conditions described in "Plant material and growth conditions" with the exception of the light intensity. The intensity during the experiment was increased to $300 \mu \mathrm{mol}$ $\mathrm{m}^{-2} \mathrm{~s}^{-1}$

\section{Water quality analysis}

Nitrate, ammonia and phosphate concentrations in the medium were determined using a HACH DR2800 machine. $\mathrm{NO}_{3}-\mathrm{N}$ was determined by the cadmium reduction method (HACH method 8171) using NitraVer®5 Nitrate Reagent Powder Pillows (absorbance measured at $500 \mathrm{~nm}$, detection range between 0.3 and $30.0 \mathrm{mg} \cdot \mathrm{l}^{-1}$ ). The $\mathrm{NH}_{4}{ }^{+} \mathrm{N}$ concentration was determined by the Nessler method (HACH Method 8038) using Nessler reagent, mineral stabilizer and polyvinyl alcohol dispersing agent (absorbance measured at $420 \mathrm{~nm}$, detection range of $\left.0.02-2.50 \mathrm{mg} \cdot \mathrm{l}^{-1}\right)$. $\mathrm{PO}_{4}{ }^{3}-\mathrm{P}$ was determined by the ascorbic acid method (HACH method 8048) using PhosVer® 3 Phosphate Reagent Powder Pillows (absorbance measured at $880 \mathrm{~nm}$, detection range of 0.02 to $\left.2.50 \mathrm{mg} \cdot \mathrm{l}^{-1}\right)$.

\section{Calculations of $\mathbf{N}$ and $\mathbf{P}$ uptake rates}

The removal rate of $\mathrm{NO}_{3}^{-}-\mathrm{N}, \mathrm{NH}_{4}{ }^{+}-\mathrm{N}$ and $\mathrm{PO}_{4}{ }^{3-}-\mathrm{P}$ was calculated for plants kept at four different plant densities. Removal rates of $\mathrm{N}$ and $\mathrm{P}$ were calculated per square meter of water surface (covered by different plant densities) per day, as well as per square meter of water area covered by fronds of Lemna minor (at different densities) per day. The following formula was used to calculate the uptake rates:

$$
\mathrm{RWS}=(\mathrm{Ci}-\mathrm{Cf}) * \mathrm{~V} / \mathrm{Aw}^{* \mathrm{t}}
$$

where RWS is the removal rate per water surface, $\mathrm{Ci}$ is the initial concentration of the nutrient, $\mathrm{Cf}$ is the final concentration of the nutrient, $\mathrm{V}$ is the volume in litre, $\mathrm{t}$ is the time in days and Aw is the surface area of water available to the plants in square meter (area of the culture container).

$$
\mathrm{RDS}=(\mathrm{Ci}-\mathrm{Cf}) * \mathrm{~V} / \mathrm{Ad} * \mathrm{t}
$$

where RDS is the removal rate per square meter of water area covered by Lemna fronds, Ci is the initial concentration of the nutrient, $\mathrm{Cf}$ is the final concentration of the nutrient, $\mathrm{V}$ is the volume in litre, $\mathrm{t}$ is the time in days and Ad is the water area covered by Lemna fronds in square meter. 
The relationship between removal rates and concentrations of $\mathrm{NO}_{3}^{-}-\mathrm{N}$ and $\mathrm{NH}_{4}{ }^{+}-\mathrm{N}$ in the SAW was analysed in more detail for the two highest plant densities $(60 \%$ and $80 \%)$, for which removal rates per surface area were highest and significantly different from the removal rates at $20 \%$ and $40 \%$. For $\mathrm{PO}_{4}{ }^{3-}-\mathrm{P}$, all the four densities were included in the analysis.

\section{Statistical analysis}

All statistical analysis was performed using IBM SPSS statistics 26. A two-way repeated measures ANOVA was conducted to determine the effects of plant density and time on the removal of $\mathrm{NO}_{3}-\mathrm{N}, \mathrm{NH}_{4}{ }^{+}-\mathrm{N}$ and $\mathrm{PO}_{4}{ }^{3}$-P. For the simple two-way interactions and simple main effects, a Bonferroni adjustment was applied. Statistical significance was accepted with $95 \%$ confidence level.

The removal rates of $\mathrm{NO}_{3}-\mathrm{N}, \mathrm{NH}_{4}{ }^{+}-\mathrm{N}$ and $\mathrm{PO}_{4}{ }^{3}$ - $\mathrm{P}$ at different plant densities were compared using a one-way ANOVA. The normality of the rates was assessed by the Shapiro-Wilk test and the homogeneity of variances by Levene's test. Post hoc analysis was performed with a Tukey test.

Linear regression was used to explore the effects of different concentrations of $\mathrm{NO}_{3}-\mathrm{N}$, $\mathrm{NH}_{4}{ }^{+}-\mathrm{N}$ and $\mathrm{PO}_{4}{ }^{3}-\mathrm{P}$ on removal rates. The linearity of the relation between the two variables was assessed by visual inspection of the scatter plot, and homoscedasticity and normality of the residuals were verified. When the variables failed to show a clear pattern on the scatter plot, a Kendall tau-b test was carried out to confirm the lack of correlation. The proportion of the variation in the removal rate explained by the concentration was determined, and dependent variable values were predicted from new independent variable values.

\section{Verification of predicted values}

Real aquaculture wastewater was collected from a fish farm in Ireland, farming rainbow trout (Oncorhynchus mykiss) and European perch (Perca fluviatilis). The wastewater contained $3.75,1.9$ and $3.6 \mathrm{mg} \cdot l^{-1}$ of, respectively, $\mathrm{NH}_{4}{ }^{+}-\mathrm{N}, \mathrm{NO}_{3}-\mathrm{N}$ and $\mathrm{PO}_{4}{ }^{3}-\mathrm{P}$. Duckweed at densities between 60 and $80 \%$ were placed in a culture container containing $100 \mathrm{ml}$ of real aquaculture wastewater. The nutrient content was measured after $24 \mathrm{~h}$, and the uptake rates were calculated in order to compare the rate of uptake from real aquaculture medium with that predicted from the experiments using synthetic aquaculture medium. The experiment was replicated 12 times.

\section{Results}

\section{Development of a synthetic aquaculture wastewater}

The literature was mined for data on the composition of freshwater aquaculture effluents and specifically concentrations of $\mathrm{NO}_{3}-\mathrm{N}, \mathrm{NH}_{4}{ }^{+}-\mathrm{N}$ and $\mathrm{PO}_{4}{ }^{3-}-\mathrm{P}$. A total of 16 articles contained relevant data for the purpose of the present study. These articles contained data on the effluents from farms culturing rainbow trout (Oncorhynchus mykiss), salmon smolt (Salmo salar), brown trout (Salmo trutta), arctic char (Salvelinus alpinus), European eel (Anguilla Anguilla), pike perch (Sander lucioperca), sturgeon (Acipenser sp.), Nile tilapia (Oreochromis niloticus), European perch (Perca fluviatilis), European sea bass (Dicentrarchus labrax), catfish (Ictalurus sp.) and bluegill (Lepomis macrochirus) (supplementary table I). There was 
substantial variation in effluent concentrations of $\mathrm{NO}_{3}-\mathrm{N}, \mathrm{NH}_{4}{ }^{+}-\mathrm{N}$ and $\mathrm{PO}_{4}{ }^{3-}-\mathrm{P}$ (Fig. 1a-c). The mean values for $\mathrm{NO}_{3}-\mathrm{N}, \mathrm{NH}_{4}{ }^{+}-\mathrm{N}$ and $\mathrm{PO}_{4}{ }^{3-}-\mathrm{P}$, in the papers reviewed, were, respectively, 25.7, 5.7 and $2.7 \mathrm{mg} \cdot \mathrm{l}^{-1}$. The highest concentration of $\mathrm{NH}_{4}{ }^{+} \mathrm{N}$ was found in a study by Gendel and Lahav (2013). The authors farmed 105 tilapia in 5001 of medium and the concentration of $\mathrm{NH}_{4}{ }^{+}-\mathrm{N}$ in the water reached $20 \mathrm{mg} \cdot \mathrm{l}^{-1}$. The highest concentration of $\mathrm{NO}_{3}-$ $\mathrm{N}\left(200 \mathrm{mg} \cdot \mathrm{l}^{-1}\right)$ was found in a study by Dalsgaard et al. (2013) in which rainbow trout was farmed at a density of $50-80 \mathrm{~kg} \cdot \mathrm{m}^{-3}$. The highest concentration of $\mathrm{PO}_{4}{ }^{3-}-\mathrm{P}$ in effluent was found by $\mathrm{Ng}$ and Chan (2018). The authors observed a concentration of $19 \mathrm{mg} \cdot \mathrm{l}^{-1} \mathrm{PO}_{4}{ }^{3-}-\mathrm{P}$ in a fish farm in China; however, they did not specify which species was farmed and at which density.

Based on the information obtained from the literature (Fig. 1, Suppl. Table I), a synthetic aquaculture waste effluent was designed that contains 25,8 and $2 \mathrm{mg} \cdot \mathrm{l}^{-1}$ of $\mathrm{NO}_{3}-\mathrm{N}, \mathrm{NH}_{4}{ }^{+}-\mathrm{N}$ and $\mathrm{PO}_{4}{ }^{3-} \mathrm{P}$, respectively. These values are the rounded up mean values calculated for the papers reviewed. SAW was supplemented with common macro- and micronutrients, to resemble eutrophic wastewater (Table 1). Other elements necessary for the growth of Lemnaceae were added in the amount and proportions suggested by Hutner (1953). The $\mathrm{pH}$ of the synthetic wastewater was 5.5.

\section{Lemna minor-mediated removal of nutrients from SAW}

The growth of $L$. minor on SAW during the 4 days of experiment was substantial. Every day, a number of fronds had to be removed in order to maintain the chosen densities. Approximately 7, 14, 20 and 25 fronds of $L$. minor were removed daily from the containers with plants at the densities of, respectively, 20\%, 40\%, 60\% and 80\%. The $\mathrm{NH}_{4}{ }^{+}-\mathrm{N}, \mathrm{NO}_{3}-\mathrm{N}$ and $\mathrm{PO}_{4}{ }^{3}-\mathrm{P}$ concentrations in the SAW were measured every day. $\mathrm{NH}_{4}{ }^{+}-\mathrm{N}$ depletion was substantial (Fig. 2a). In most of the experiments with a plant density of $60 \%$ and $80 \%$, the concentration of $\mathrm{NH}_{4}{ }^{+}-\mathrm{N}$ in the medium fell to just above zero after 4 days. The decrease in the concentration of $\mathrm{NH}_{4}{ }^{+}-\mathrm{N}$ ranged between $6.17 \pm 0.33$ (at a plant density of $20 \%$ ) and $7.67 \pm 0.13$ (at a plant

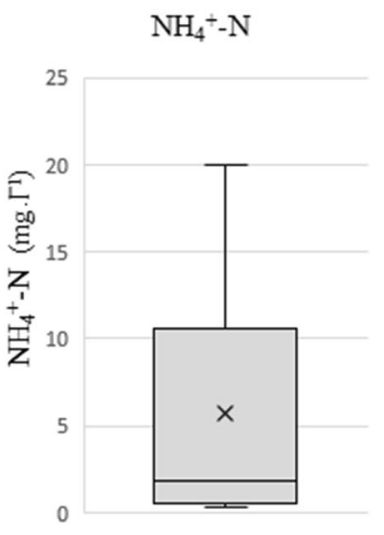

(a)

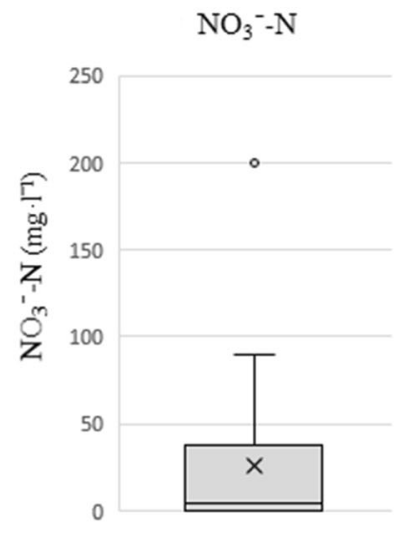

(b)

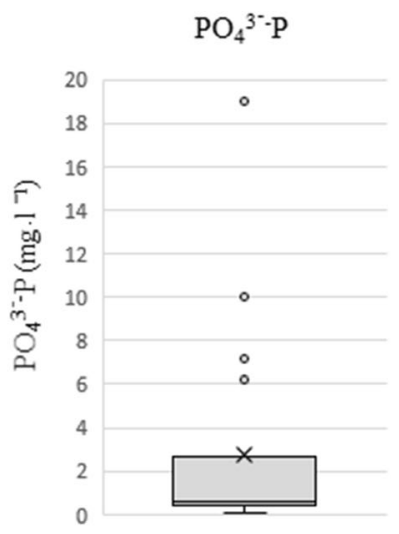

(c)

Fig. 1 Concentrations in freshwater aquaculture effluents of $\mathrm{NH}_{4}{ }^{+}-\mathrm{N}(\mathrm{a}), \mathrm{NO}_{3}-\mathrm{N}$ (b) and $\mathrm{PO}_{4}{ }^{3-}-\mathrm{P}$ (c) found in the literature. The data were collected from 16 articles (Supplementary Table I). All the concentrations were converted in milligrams per litre. The $\mathrm{x}$ indicates the mean, the horizontal line within the box indicates the median, and the lower and upper extremes of the box indicate respectively first and third quartiles. Grey circles are outliers 
Table 1 Composition of synthetic aquaculture wastewater

Concentration $\left(\mathrm{mg} \cdot \mathrm{l}^{-1}\right)$

$\begin{array}{ll}(\mathrm{NH} 4) 2 \mathrm{SO} 4 & 40 \\ \mathrm{KNO} 3 & 73 \\ \mathrm{Ca}(\mathrm{NO} 3) \cdot 4 \mathrm{H} 2 \mathrm{O} & 186.15 \\ \mathrm{KH} 2 \mathrm{PO} 4 & 8.7 \\ \mathrm{CaSO} 4 & 328.6 \\ \mathrm{MgSO}_{4} \cdot 4 \mathrm{H} 2 \mathrm{O} & 738 \\ \mathrm{~K} 2 \mathrm{SO} 4 & 471.5 \\ \mathrm{ZnSO} 4 \cdot 7 \mathrm{H} 2 \mathrm{O} & 1 \\ \mathrm{MnSO} 4 \mathrm{H} 2 \mathrm{O} & 0.1 \\ \mathrm{CuSO} 45 \mathrm{H} 2 \mathrm{O} & 0.03 \\ \mathrm{Na} 2 \mathrm{MoO} 42 \mathrm{H} 2 \mathrm{O} & 0.1 \\ \text { Ferric citrate } & 1 \\ \text { EDTA Na } & 0.029 \\ \mathrm{H} 3 \mathrm{BO} 3 & 1\end{array}$

density of $80 \%) \mathrm{mg} \cdot \mathrm{l}^{-1}$. The biggest decrease in the concentration of $\mathrm{NH}_{4}{ }^{+}-\mathrm{N}$ was observed during the first $24 \mathrm{~h}$. Overall, less $\mathrm{NH}_{4}{ }^{+}-\mathrm{N}$ was removed from SAW at lower plant densities. A two-way repeated measures ANOVA revealed a significant interaction between time and density $(\mathrm{p}<0.01)$. The simple main effects of the plant density and time on $\mathrm{NH}_{4}{ }^{+}-\mathrm{N}$ concentration were significant, with both $\mathrm{p}<0.01$. Plants at a density of $80 \%$ removed more $\mathrm{NH}_{4}{ }^{+}-\mathrm{N}$ than plants at density $40 \%(\mathrm{p}<0.01)$ and $20 \%(\mathrm{p}<0.01)$. Plants at a density of $60 \%$ removed more $\mathrm{NH}_{4}{ }^{+}-\mathrm{N}$ than plants at density $40 \%(\mathrm{p}<0.001)$ and $20 \%(\mathrm{p}<0.01)$. Plants at a density of $40 \%$ removed more $\mathrm{NH}_{4}{ }^{+}-\mathrm{N}$ than plants at density $20 \%(\mathrm{p}<0.001)$.

The concentration of $\mathrm{NO}_{3}-\mathrm{N}$ in the medium decreased slowly over the 4 days of monitoring (Fig. 2b). The concentration of $\mathrm{NO}_{3}-\mathrm{N}$ in the $\mathrm{SAW}$ reached values as low as $13.5 \pm 1.6 \mathrm{mg} \cdot \mathrm{l}^{-1}$ at the highest plant density and after 4 days. A two-way repeated measures ANOVA highlighted that there was significant interaction between time and density on $\mathrm{NO}_{3}-\mathrm{N}$ concentration $(\mathrm{p}=0.047)$. The simple main effects of time and density were also significant $(\mathrm{p}=$ 0.005 and 0.02 , respectively). Plants at a density of $80 \%$ removed more $\mathrm{NO}_{3}-\mathrm{N}$ than plants at density 20\% (p < 0.011) and 40\% ( $\mathrm{p}=0.035)$.

The daily decrease in $\mathrm{PO}_{4}{ }^{3}$-P concentration was constant during the 4 days of experiment, (Fig. 2c). The concentration of $\mathrm{PO}_{4}{ }^{3}-\mathrm{P}$ in the SAW reached values as low as $0.89 \pm 0.31$ $\mathrm{mg} \cdot \mathrm{l}^{-1}$ after 4 days and at the density of $60 \%$. There was no significant two-way interaction between time and plant density on the $\mathrm{PO}_{4}{ }^{3}$-P concentration. Only time had a significant effect, with $\mathrm{p}<0.001$.

\section{Daily nutrient removal per square meter of water surface and per square meter of water area covered by Lemna fronds}

The absolute nutrient removal rate during the first $24 \mathrm{~h}$ of the experiment was calculated based on the volume of SAW used in the experiment and expressed per square meter of water surface (Fig. 3a) or per square meter of water area covered by Lemna fronds (Fig. 3b). The rates calculated were plotted as a function of the plant density. When the removal rates of both forms of $\mathrm{N}$ were calculated per square meter of water surface, they increased with increasing plant density. The highest removal rates of $\mathrm{NH}_{4}{ }^{+}-\mathrm{N}$ were $157.61 \pm 10.57 \mathrm{mg} \cdot \mathrm{m}^{-2} \cdot$ day $^{-1}$, achieved at a plant density of $80 \%$. The lowest rate of $\mathrm{NH}_{4}{ }^{+}-\mathrm{N}$ removal was $99.12 \pm 6.41$ 
$\mathrm{NH}_{4}{ }^{+}-\mathrm{N}$ depletion

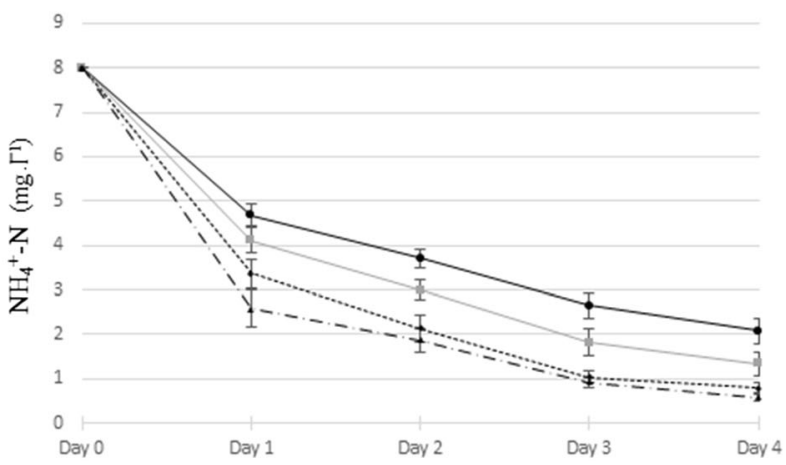

(a)

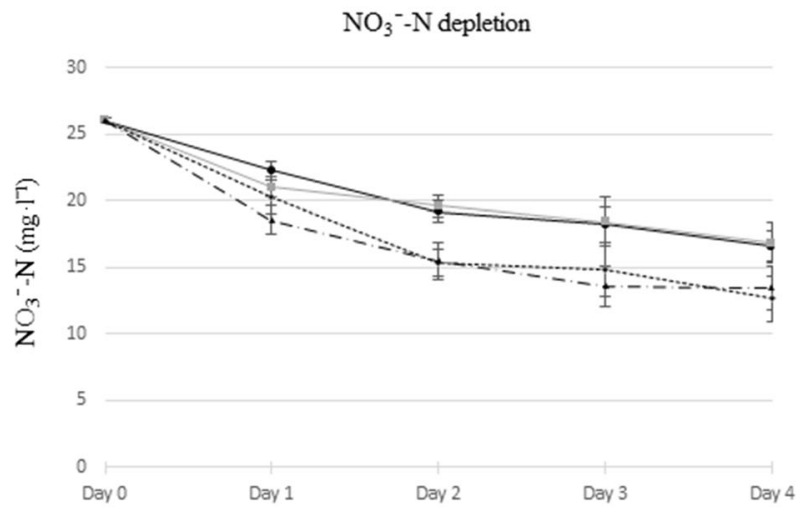

(b)

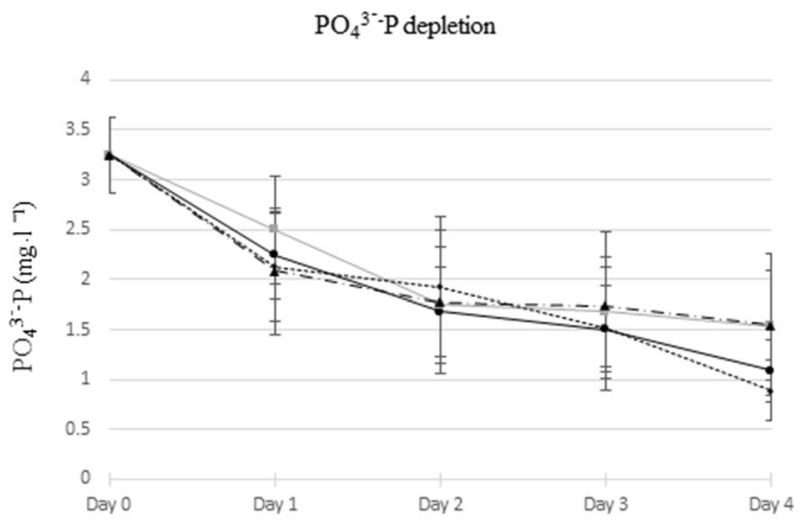

(c)

$\longrightarrow 20 \%=40 \% \quad \ldots+\cdots 60 \% \quad$ - 2 - $60 \%$

Fig. 2 Decrease over time of $\mathrm{NH}_{4}{ }^{+}-\mathrm{N}(\mathrm{a}), \mathrm{NO}_{3}-\mathrm{N}$ (b) and $\mathrm{PO}_{4}{ }^{3-}-\mathrm{P}$ (c) in synthetic aquaculture wastewater with L. minor at four different densities $(20 \%, 40 \%, 60 \%$ and $80 \%)$. Slightly higher nutrient concentrations on day 0 relate to carry-over from standard medium to experimental medium. $\mathrm{N}=12$, bars are standard errors 
Daily removal rate per $\mathrm{m}^{2}$ of water surface

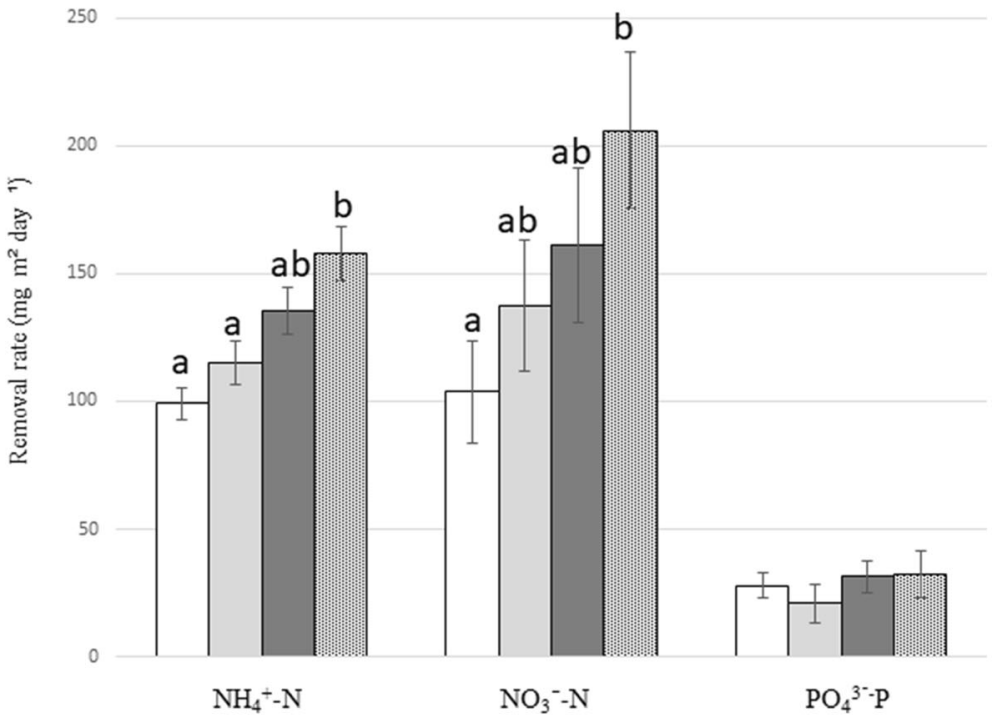

(a)

Daily removal rate per $\mathrm{m}^{2}$ of duckweed surface

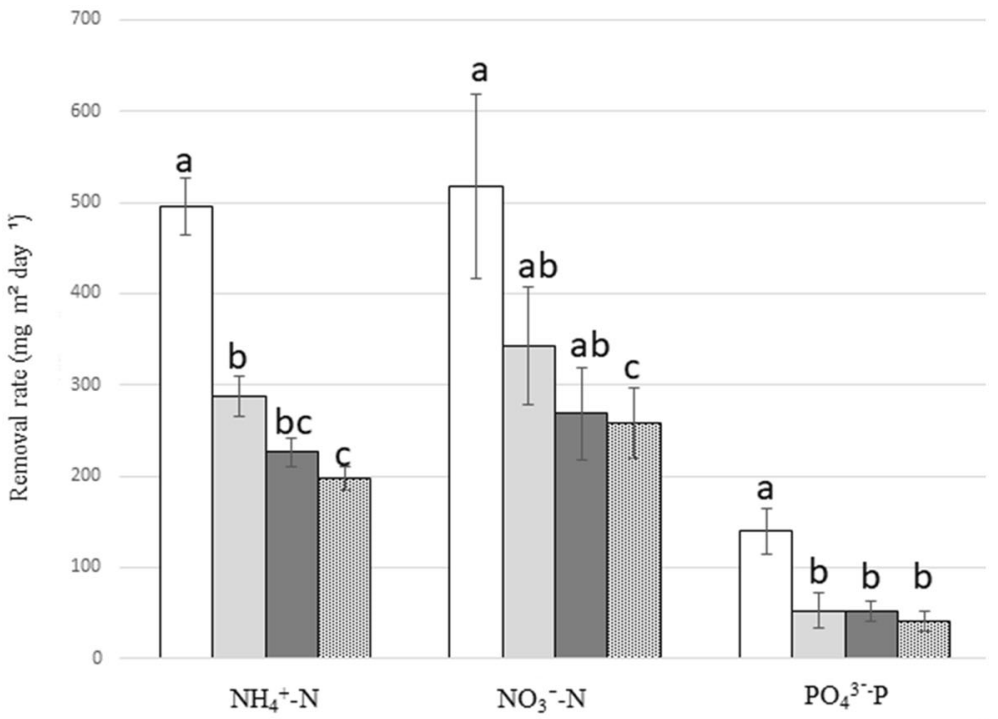

(b)

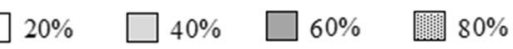

Fig. 3 Nutrient removal rate per square meter of water surface (a) and per square meter of $L$. minor covering the water surface (b), at different plant densities $(20 \%, 40 \%, 60 \%, 80 \%)$ and measured during the first $24 \mathrm{~h}$ of experiments. Different letters indicate significant differences. $\mathrm{N}=12$, bars are standard errors 
Simple scatters of removal rate by concentration

$\mathrm{NH}_{4}^{+}-\mathrm{N}$

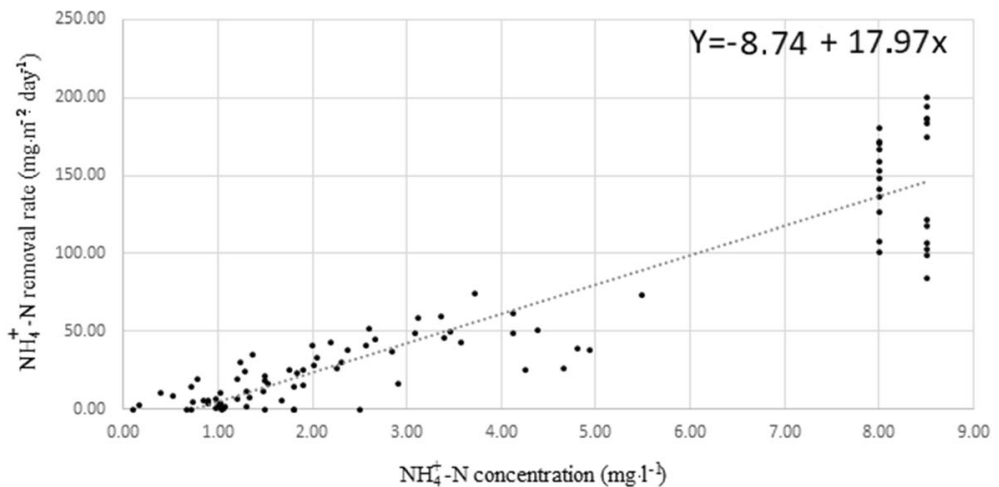

(a)

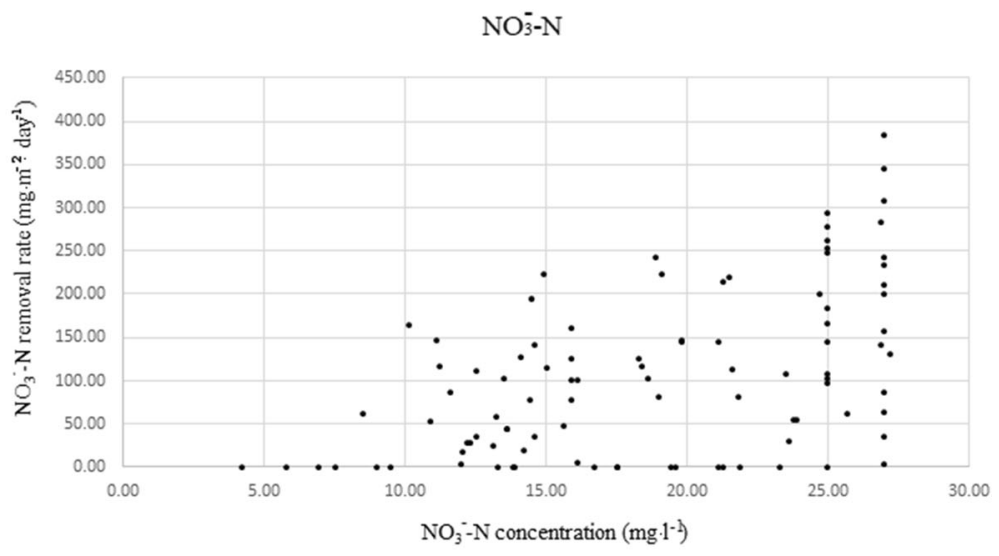

(b)

$\mathrm{PO}_{4}^{3-\mathrm{P}}$

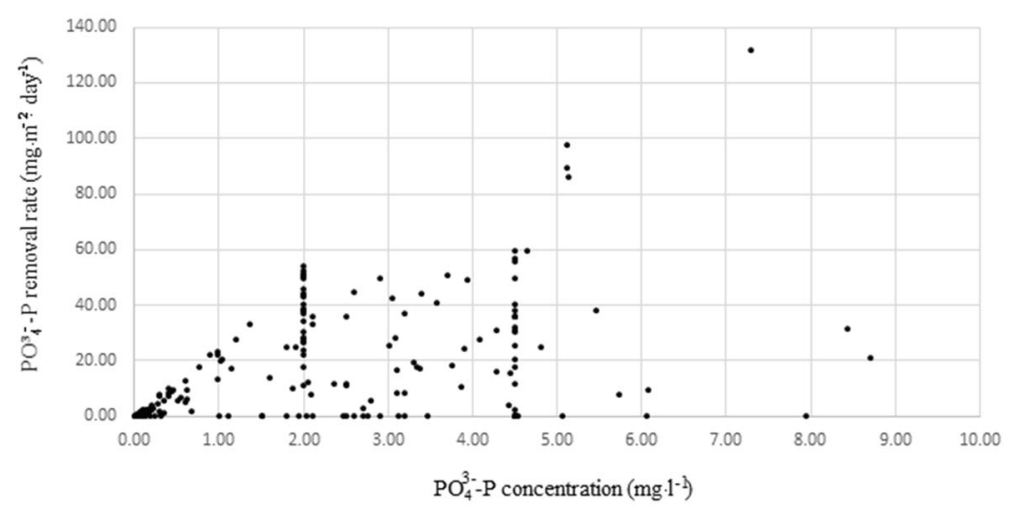

(c) 
Fig. 4. Simple scatter plot of daily $\mathrm{NO}_{3}-\mathrm{N}(\mathrm{a}), \mathrm{NH}_{4}{ }^{+}-\mathrm{N}$ (b) and $\mathrm{PO}_{4}{ }^{3-}-\mathrm{P}$ (c) removal rates expressed per square meter of water surface area as a function of nutrient concentration in the medium. $\mathrm{For}_{\mathrm{NH}_{4}}{ }_{-} \mathrm{N}$, the fit lines and the regression equations are also indicated. Dots represent individual measurements. $\mathrm{NH}_{4}{ }^{+}-\mathrm{N}$ concentrations of 8 $\mathrm{mg} \cdot 1^{1}, \mathrm{NO}_{3}-\mathrm{N}$ concentrations of $25 \mathrm{mg} \cdot 1^{1}$ and $\mathrm{PO}_{4}{ }^{3-} \mathrm{P}$ concentrations of $2.5 \mathrm{mg} \cdot 1^{1}$ represent the initial concentrations used in uptake experiments. Concentrations higher to SAW concentrations are due to carryover from standard medium to experimental medium

$\mathrm{mg} \cdot \mathrm{m}^{-2} \cdot$ day $^{-1}$, achieved at a plant density of $20 \%$. Plants at the density of $80 \%$ removed significantly more $\mathrm{NH}_{4}{ }^{+}-\mathrm{N}$ than plants at a density of $20 \%(\mathrm{p}<0.01)$ and $40 \%(\mathrm{p}<0.01)$. The highest removal rate of $\mathrm{NO}_{3}-\mathrm{N}$ was $205.99 \pm 30.71 \mathrm{mg} \cdot \mathrm{m}^{-2} \cdot$ day ${ }^{-1}$, achieved at a plant density of $80 \%$, while the lowest was $103.61 \pm 20.27 \mathrm{mg} \cdot \mathrm{m}^{-2}$. day ${ }^{-1}$, achieved at the density of $20 \%$. Plants at the density of $80 \%$ removed significantly more $\mathrm{NO}_{3}-\mathrm{N}$ than plants at the density of $20 \%(\mathrm{p}=0.045)$.

In contrast to what was observed for rate calculated per square meter of water surface, when the removal rate was calculated per square meter of plants covering the water surface, it decreased with the increasing plant density. The highest removal rates of $\mathrm{NH}_{4}{ }^{+}-\mathrm{N}$ were $495.6 \pm$ $32.05 \mathrm{mg} \cdot \mathrm{m}^{-2} \cdot \mathrm{day}^{-1}$, achieved at a plant density of $20 \%$. The lowest rate of $\mathrm{NH}_{4}{ }^{+}-\mathrm{N}$ removal was $197.01 \pm 13.21 \mathrm{mg} \cdot \mathrm{m}^{-2}$. day ${ }^{-1}$, achieved at a plant density of $80 \%$. Plants at the density of $20 \%$ removed significantly more $\mathrm{NH}_{4}{ }^{+}-\mathrm{N}$ than plants with a density of $80 \%(\mathrm{p}<0.01), 60 \%(\mathrm{p}$ $<0.01)$ and $40 \%(\mathrm{p}<0.01)$; the removal of $\mathrm{NH}_{4}{ }^{+}-\mathrm{N}$ at $40 \%$ was also significantly higher than the removal at $80 \%(\mathrm{p}=0.025)$. The highest removal rate of $\mathrm{NO}_{3}-\mathrm{N}$ was $518.05 \pm 101.39$ $\mathrm{mg} \cdot \mathrm{m}^{-2}$. day ${ }^{-1}$, achieved at a plant density of $20 \%$, while the lowest was $257.49 \pm 38.38$ $\mathrm{mg} \cdot \mathrm{m}^{-2} \cdot$ day $^{-1}$, achieved at the density of $80 \%$. Plants at the density of $20 \%$ removed significantly more $\mathrm{NO}_{3}-\mathrm{N}$ than plants at the density of $80 \%(\mathrm{p}=0.045)$.

The removal rate of $\mathrm{PO}_{4}{ }^{3}$-P per square meter of water ranged between $20.87 \pm 7.72$ and $32.43 \pm 9.1 \mathrm{mg} \cdot \mathrm{m}^{-2} \cdot \mathrm{day}^{-1}$, with no significant differences between densities. When calculated per square meter of plant covering the water surface, the highest removal rate, $139.46 \pm 24.15$ $\mathrm{mg} \cdot \mathrm{m}^{-2} \cdot$ day $^{-1}$, was observed at the plant density of $20 \%$. At this density, the removal rate was significantly higher than at $40 \%(\mathrm{p}<0.01), 60 \%(\mathrm{p}<0.01)$ and $80 \%(\mathrm{p}<0.01)$.

The detailed results of the statistical analyses are reported in tables contained in supplementary material 1 .

\section{Removal rates at different nutrient concentrations in the SAW}

The daily nutrient removal rate for all sampling time-points and recalculated per square meter of water surface was plotted as a function of the measured concentrations of $\mathrm{NH}_{4}{ }^{+}-\mathrm{N}, \mathrm{NO}_{3}-\mathrm{N}$ and $\mathrm{PO}_{4}{ }^{3}-\mathrm{P}$ in $\mathrm{SAW}$. For $\mathrm{NH}_{4}{ }^{+}-\mathrm{N}$ and $\mathrm{NO}_{3}-\mathrm{N}$, data are presented for plants kept at 60 and $80 \%$, at which densities the uptake rates are most substantial. For $\mathrm{PO}_{4}{ }^{3}-\mathrm{P}$, the removal rates at all the densities tested were included as no significant differences between densities were highlighted in the previous analysis. A visual inspection of the scatter plots highlighted a linear relationship between daily $\mathrm{NH}_{4}{ }^{+}-\mathrm{N}$ removal rate and $\mathrm{NH}_{4}{ }^{+}-\mathrm{N}$ concentration (Fig. 4a). This relationship was further analysed using regression analysis. The analysis shows that the concentration of $\mathrm{NH}_{4}{ }^{+}-$ $\mathrm{N}$ in the medium significantly predicts the removal rate of the compound in the water $(\mathrm{p}<0.01)$. The medium concentration accounted for $86 \%\left(\mathrm{R}^{2}=86 \%\right)$ of the variability in removal rate. A Kendall tau-b correlation was run to determine the relationship between concentration of $\mathrm{NO}_{3}-\mathrm{N}$ or $\mathrm{PO}_{4}{ }^{3-} \mathrm{P}$ and daily removal rate. This test was selected as a visual inspection of the scatter plots failed to show a linear relationship 
between variables. There was a weak association between both nutrients and daily removal rate, which was not statistically significant $(\tau \mathrm{b}=0.127, \mathrm{p}=.681$, and $\tau \mathrm{b}=$ $0.111, \mathrm{p}=.702$ respectively). Because of the lack of correlation between variables, the regression analysis was not carried out for $\mathrm{NO}_{3}-\mathrm{N}$ and $\mathrm{PO}_{4}{ }^{3-}-\mathrm{P}$ data (Fig. 4b, c).

The observed regression line was used to predict the uptake rate of $\mathrm{NH}_{4}{ }^{+}-\mathrm{N}$ from real, farmcollected, aquaculture wastewater (containing $3.75 \mathrm{mg} \cdot \mathrm{l}^{-1}$ of $\mathrm{NH}_{4}{ }^{+}-\mathrm{N}$ ). The predicted uptake rate was $58.8 \mathrm{mg} \cdot \mathrm{m}^{-2}$. day ${ }^{-1}$. The observed uptake rate of $\mathrm{NH}_{4}{ }^{+} \mathrm{N}$ by duckweed grown in the real aquaculture wastewater was $53.6 \pm 0.4 \mathrm{mg} \cdot \mathrm{m}^{-2} \cdot$ day $^{-1}$ (Fig. 5).

\section{Discussion}

A key challenge in the design of IMTA systems is the balance between fed and extractive species (Wei et al. 2017; Fang et al. 2019; Nardelli et al. 2019). Where ES are algae or plants, it is essential to consider their intrinsic growth and nutrient uptake characteristics. These characteristics vary in response to changes in the composition of the wastewater (Kwon et al. 2013), as well as in response to environmental parameters such as temperature and light (Iasimone et al. 2018). Growth and nutrient uptake are also species specific (Khatun et al. 2016; Yongpisanphop et al. 2017; Queiroz et al. 2020). Here, uptake of $\mathrm{NO}_{3}-\mathrm{N}, \mathrm{NH}_{4}{ }^{+}-\mathrm{N}$ and $\mathrm{PO}_{4}{ }^{3}$-P by $L$. minor was analysed under controlled conditions using a synthetic aquaculture wastewater and various plant densities, in order to obtain quantitative information on the remediation potential of this species.

\section{Development of a synthetic aquaculture wastewater for controlled experiments}

The development of synthetic wastewater to enable reproducible testing of the efficiency of different water remediation systems is increasingly prevalent (e.g. Visvanathan et al. 2008;

Daily removal rate per $\mathrm{m}^{2}$ of real aquaculture wastewater

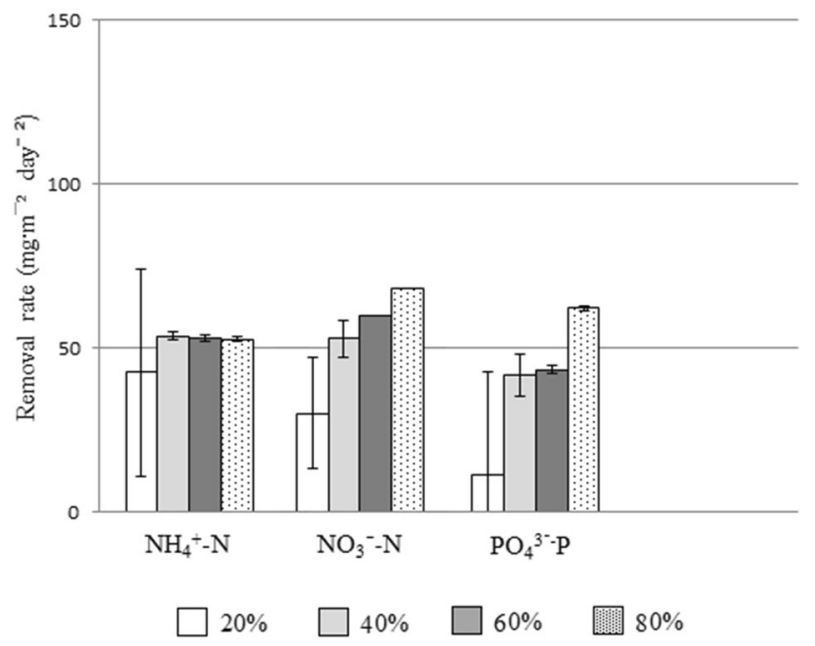

Fig. 5. Nutrient removal rate per square meter of real aquaculture wastewater surface at different plant densities $(20 \%, 40 \%, 60 \%, 80 \%)$, measured during the first $24 \mathrm{~h}$ of experiments. The wastewater contained $3.75,1.9$ and $3.6 \mathrm{mg} \cdot l^{-1}$ of, respectively, $\mathrm{NH}_{4}{ }^{+}-\mathrm{N}, \mathrm{NO}_{3}-\mathrm{N}$ and $\mathrm{PO}_{4}{ }^{3-}-\mathrm{P}$ 
Saleem et al. 2011; Ansari et al. 2017; Barnharst et al. 2018; Walsh et al. 2020). The use of such a standardised medium facilitates studies on the impacts of other parameters, such as plant species, plant density, climatic factors, microbial populations and IMTA system design parameters. Previously, a SAW was used by Ng and Chan (2018) to test the phytoremediation ability of Spirodela polyrhiza, Salvinia molesta and Lemna sp. The authors based the $\mathrm{NH}_{4}{ }^{+}-\mathrm{N}$ and $\mathrm{PO}_{4}{ }^{3}-\mathrm{P}$ concentrations (20 and $19 \mathrm{mg} \cdot \mathrm{l}^{-1}$ respectively) in their synthetic wastewater on the concentrations measured at a local fish farm. In the current study, a SAW was developed on the basis of realistic concentrations of $\mathrm{NH}_{4}{ }^{+}-\mathrm{N}, \mathrm{NO}_{3}-\mathrm{N}$ and $\mathrm{PO}_{4}{ }^{3}-\mathrm{P}$ in freshwater aquaculture effluents. Selected papers refer to a variety of fish farms, farming different species at different densities. Thus, the developed SAW is a generic medium that can be used as a proxy representing effluent from a broad range of freshwater fish farms.

\section{Removal of nutrients from SAW}

In this study, the removal rate of nutrients was determined by measuring the concentration of the nutrients in the SAW every day. The experiment was carried out in aseptic conditions. Therefore, it is reasonable to assume that the nutrients removed from the SAW were taken up by the plants as the microbial activity was negligible. Given the small scale of the experiments, it was not possible to determine the amount of nutrients in the plant biomass.

The developed SAW is a suitable growth medium for L. minor, with both plant growth and nutrient removal being substantial. A comparison of the $\mathrm{NH}_{4}{ }^{+}-\mathrm{N}$ uptake rate from real farm aquaculture wastewater $\left(58.8 \mathrm{mg} \cdot \mathrm{m}^{-2} \cdot \mathrm{day}^{-1}\right.$ at a concentration of $\left.3.75 \mathrm{mg} \cdot \mathrm{l}^{-1}\right)$ and the rates obtained using SAW $\left(53.6 \pm 0.4 \mathrm{mg} \cdot \mathrm{m}^{-2} \cdot\right.$ day $^{-1}$ at $\left.2.4 \mathrm{mg} \cdot \mathrm{l}^{-1}\right)$ shows good agreement. Thus, the developed SAW proved to be a reliable representative of real aquaculture wastewater.

Rapid removal of $\mathrm{NH}_{4}{ }^{+}-\mathrm{N}$ and $\mathrm{PO}_{4}{ }^{3}$-P from SAW was observed during the first $24 \mathrm{~h}$ of the experiment. Comparatively, the decrease of $\mathrm{NO}_{3}{ }^{-} \mathrm{N}$ in the $\mathrm{SAW}$ was lower. The relatively slow removal of $\mathrm{NO}_{3}{ }^{-}-\mathrm{N}$ is most likely related to the presence of $\mathrm{NH}_{4}{ }^{+}-\mathrm{N}$ in the SAW. When both forms of nitrogen are present in a medium, Lemnaceae prefer to take up $\mathrm{NH}_{4}{ }^{+}-\mathrm{N}$ (Feller and Erismann 1971), probably as the direct conversion of ammonia into protein is a more energy-efficient process (El-Shafai et al. 2007). The measured removal rates of the two combined forms of nitrogen from SAW are slightly lower than those reported in the literature. For example, in the literature, values range from 500 to $2100 \mathrm{mg} \cdot \mathrm{m}^{-2} \cdot \mathrm{day}^{-1}$ (Körner and Vermaat 1998; Cheng et al. 2002; Mohedano et al. 2012). The phosphorus removal rates measured in this study are also in the lower portion of the published range (i.e. from 20 to 590 $\mathrm{mg} \cdot \mathrm{m}^{-2} \cdot \mathrm{day}^{-1}$ ) (Körner and Vermaat 1998; Cheng et al. 2002; Mohedano et al. 2012). The absence of bacterial and algal activity under the used experimental conditions is probably responsible for the relatively low removal of nutrients.

Following the first $24 \mathrm{~h}$, removal rates of all nutrients decreased, and this was associated with lower nutrient concentrations in the used stationary system. To analyse the relationship between removal rates and nutrient concentration in the SAW in more detail, removal rates (mg $\cdot \mathrm{m}^{-2}$. day ${ }^{-1}$ of water surface) of $\mathrm{NH}_{4}{ }^{+}-\mathrm{N}, \mathrm{NO}_{3}-\mathrm{N}$ and $\mathrm{PO}_{4}{ }^{3}-\mathrm{P}$ were plotted against the concentration of the compounds in the $\mathrm{SAW}$. For $\mathrm{NO}_{3}-\mathrm{N}$ and $\mathrm{PO}_{4}{ }^{3}-\mathrm{P}$, the relationships between removal rate and the concentration were not well defined. However, the removal rate of $\mathrm{NH}_{4}{ }^{+}-\mathrm{N}$ linearly decreased with decreasing concentration in the medium. These data cannot be directly interpreted as meaning that $\mathrm{NH}_{4}{ }^{+}-\mathrm{N}$ is limiting for growth, as growth is likely to be more closely related to internal redistribution of nutrients, rather than uptake (Kufel et al. 2012). Nevertheless, the ability to predict removal rates at different nutrient concentrations is 
of fundamental importance when designing duckweed-based phytoremediation system as it can inform attempts to achieve a balance between fed and extractive species.

\section{Effect of plant density on the removal rates}

As removal of nitrogen and phosphorus is essentially surface area-related processes, the plant density in the system needs to be considered. In the present study, the removal rate was calculated both per square meter duckweed covering the water surface and per square meter of water surface. The two different approaches reflect two different aspects of duckweed-based wastewater systems. The removal rate per square meter of water is an important tool to predict the efficiency of the system from the water-restoration point of view. On the other hand, the analysis of the removal rate calculated on the basis of plant surface reveals physiological characteristics that can potentially reflect on the nutritional values of the plants.

The duckweed density relates directly to system management and harvest protocols. More plants will result in more nutrient uptake capacity. Indeed, the data show that the removal rate per square meter of water surface was higher at higher plant densities. However, the removal rate per square meter of duckweed was highest at the lowest densities. It has been argued that the increase in plant density leads to intraspecific competition, which is associated with a slowdown in nutrient removal and/or growth (Clatworthy and Harper 1962; Rejmánek et al. 1989). The higher removal rate at low plant density could be associated with different biochemical compositions of the biomass produced, and this aspect should be investigated further. It has been shown that the most efficient plant density for nutrient removal is around 80\% (Verma and Suthar 2015). Furthermore, it has been shown that at high-density plants not only maximise nutrient removal, but also block sunlight penetration in the water column, impeding growth of phytoplankton and other algae (Roijackers et al. 2004).

Nutrient removal by Lemnaceae needs to be analysed in more detail in terms of impacts on growth and nutritional value. Duckweed is considered a potential crop plant for animal feed as well as human nutrition (De Beukelaar et al. 2019), particularly in the context of the circular economy. The optimization of the nutritional value of these plants is therefore of major interest (Appenroth et al. 2018).

\section{Conclusions}

The present work lays the foundation for a more scientific approach to the design of duckweed-based aquaculture wastewater treatment systems. The results presented here highlight the importance to consider the load of nutrients in the wastewater and its effect on the plant's ability to remove them, in order to design an efficient system.

Supplementary Information The online version contains supplementary material available at https://doi.org/ 10.1007/s10499-021-00736-Z.

Author contribution Conceptualization and methodology: Simona Paolacci and Marcel Jansen; formal analysis and investigation: Simona Paolacci and Vlastimil Stejskal; writing and original draft preparation: Simona Paolacci; writing, review and editing: Marcel Jansen, Vlastimil Stejskal and Simona Paolacci; funding acquisition: Marcel Jansen; supervision: Marcel Jansen. 
Funding Open Access funding provided by the IReL Consortium. The present study was funded by Bord Iascaigh Mhara, Irish agency for fishery and seafood (grant 17/KGS/005).

Data availability The datasets used and/or analysed during the current study are available from the corresponding author on reasonable request.

\section{Declarations}

Ethics approval Not applicable.

Consent to participate Not applicable.

Consent to publish Not applicable.

Competing interests The authors declare no competing interests.

Open Access This article is licensed under a Creative Commons Attribution 4.0 International License, which permits use, sharing, adaptation, distribution and reproduction in any medium or format, as long as you give appropriate credit to the original author(s) and the source, provide a link to the Creative Commons licence, and indicate if changes were made. The images or other third party material in this article are included in the article's Creative Commons licence, unless indicated otherwise in a credit line to the material. If material is not included in the article's Creative Commons licence and your intended use is not permitted by statutory regulation or exceeds the permitted use, you will need to obtain permission directly from the copyright holder. To view a copy of this licence, visit http://creativecommons.org/licenses/by/4.0/.

\section{References}

Ahmed M, Lorica MH (2002) Improving developing country food security through aquaculture developmentlessons from Asia. Food Policy 27(2):125-141 https://www.sciencedirect.com/science/article/pii/ S0306919202000076

Ahmed N, Thompson S, Glaser M (2019) Global aquaculture productivity, environmental sustainability, and climate change adaptability. Environ Manag 63(2):159-172. https://doi.org/10.1007/s00267-018-1117-3

Allison EH (2011) Aquaculture, fisheries, poverty and food security: working paper 2011-65. World Fish Centre. http://www.worldfishcenter.org/resource_centre/WF_2971.pdf

Ansari FA, Singh P, Guldhe A, Bux F (2017) Microalgal cultivation using aquaculture wastewater: integrated biomass generation and nutrient remediation. Algal Res 21:169-177. https://doi.org/10.1016/j.algal.2016.11. 015

Appenroth KJ, Sree KS, Bog M, Ecker J, Seeliger C, Böhm V, Lorkowski S, Sommer K, Vetter W, TolzinBanasch K, Kirmse R (2018) Nutritional value of the duckweed species of the genus Wolffia (Lemnaceae) as human food. Front Chem 6:483. https://doi.org/10.3389/fchem.2018.00483

Barnharst T, Rajendran A, Hu B (2018) Bioremediation of synthetic intensive aquaculture wastewater by a novel feed-grade composite biofilm. Int Biodeterior Biodegradation 126:131-142. https://doi.org/10.1016/j.ibiod. 2017.10.007

Chandra R, Dubey NK, Kumar V (2017) Phytoremediation of environmental pollutants. CRC Press. Taylor \& Francis Group, Boca Raton

Cheng J, Landesman L, Bergmann B et al (2002) Nutrient removal from swine lagoon liquid by Lemna minor 8627. Trans ASAE 45:1003-1010 https://www.academia.edu/25463406/Nutrient_Removal_from_Swine_ Lagoon_Liquid_by_Lemna_Minor_8627

Clatworthy $\overline{\mathrm{JN}}$, Harper $\overline{\mathrm{JL}}(1962)$ The comparative biology of closely related species living in the same area: V. inter and intraspecific interference within cultures of Lemna spp. and Salvinia natans. J Exp Bot 13(2):307324. https://doi.org/10.2307/23686741

Cornel GE, Whoriskey FG (1993) The effects of rainbow trout (Oncorhynchus mykiss) cage culture on the water quality, zooplankton, benthos and sediments of Lac du Passage, Quebec. Aquaculture 109(2):101-117. https://doi.org/10.1016/0044-8486(93)90208-G 
Correll DL (1998) The role of phosphorus in the eutrophication of receiving waters: a review. J Environ Qual 27(2):261-266. https://doi.org/10.2134/jeq1998.00472425002700020004x

Dalsgaard J, Lund I, Thorarinsdottir R, Drengstig A, Arvonen K, Pedersen PB (2013) Farming different species in RAS in Nordic countries: current status and future perspectives. Aquac Eng 53:2-13. https://doi.org/10. 1016/j.aquaeng.2012.11.008

De Beukelaar MF, Zeinstra GG, Mes JJ, Fischer AR (2019) Duckweed as human food. The influence of meal context and information on duckweed acceptability of Dutch consumers. Food Qual Prefer 71:76-86. https:// doi.org/10.1016/j.foodqual.2018.06.005

El-Shafai S, El-Gohary FA, Nasr FA, Van Der Steen NP, Gijzen HJ (2007) Nutrient recovery from domestic wastewater using a UASB-duckweed ponds system. Bioresour Technol 98(4):798-807. https://doi.org/10. 1016/j.biortech.2006.03.011

Fang J, Fang J, Chen Q, Mao Y, Jiang Z, Du M, Gao Y, Lin F (2019) Assessing the effects of oyster/kelp weight ratio on water column properties: an experimental IMTA study at Sanggou Bay, China. J Oceanol Limnol 38:1-11. https://doi.org/10.1007/s00343-019-9109-6

FAO (2001). The state of food and agriculture 2001 (No. 33). Food \& Agriculture Organization of the United Nations. Rome. http://www.fao.org/3/a-y1500e.pdf

FAO (2018) Rome: 2018. The state of world fisheries and aquaculture. Rome. http://www.fao.org/documents/ card/en/c/I9540EN/

Feller U, Erismann KH (1971) Einfluss der Beleuchtungsstärke auf die Ammonium-und Nitrataufnahme bei Lemna minor. Verhandlungen der Schweizerischen Naturforschenden Gesellschaft 151:96-99

Gendel Y, Lahav O (2013) A novel approach for ammonia removal from fresh-water recirculated aquaculture systems, comprising ion exchange and electrochemical regeneration. Aquac Eng 52:27-38. https://doi.org/ 10.1016/j.aquaeng.2012.07.005

Guillen J, Asche F, Carvalho N, Polanco JMF, Llorente I, Nielsen R, Nielsen R, Nielsen M, Villasante S (2019) Aquaculture subsidies in the European Union: evolution, impact and future potential for growth. Mar Policy 104:19-28. https://doi.org/10.1016/j.marpol.2019.02.045

Hutner SH (1953) Comparative physiology of heterotrophic growth in higher plants. In: Growth and Differentiation in Plants. Iowa State College Press, pp 417-447

Iasimone F, Panico A, De Felice V, Fantasma F, Iorizzi M, Pirozzi F (2018) Effect of light intensity and nutrients supply on microalgae cultivated in urban wastewater: biomass production, lipids accumulation and settleability characteristics. J Environ Manag 223:1078-1085. https://doi.org/10.1016/j.jenvman.2018.07. 024

Jennings S, Stentiford GD, Leocadio AM, Jeffery KR, Metcalfe JD, Katsiadaki I, Auchterlonie NA, Mangi SC, Pinnegar JK, Ellis T, Peeler EJ (2016) Aquatic food security: insights into challenges and solutions from an analysis of interactions between fisheries, aquaculture, food safety, human health, fish and human welfare, economy and environment. Fish Fish 17(4):893-938. https://doi. org/10.1111/faf.12152

Khatun A, Pal S, Mukherjee AK, Samanta P, Mondal S, Kole D, Chandra P, Ghosh AR (2016) Evaluation of metal contamination and phytoremediation potential of aquatic macrophytes of East Kolkata Wetlands, India. Environ Health Toxicol 31. https://doi.org/10.5620/eht.e2016021

Körner S, Vermaat JE (1998) The relative importance of Lemna gibba L., bacteria and algae for the nitrogen and phosphorus removal in duckweed-covered domestic wastewater. Water Res 32:3651-3661. https://doi.org/ 10.1016/S0043-1354(98)00166-3

Kufel L, Strzałek M, Wysokińska U, Biardzka E, Oknińska S, Ryś K (2012) Growth rate of duckweeds (Lemnaceae) in relation to the internal and ambient nutrient concentrations-testing the Droop and Monod models. Pol J Ecol 60(2):241-249 http://www.miiz.waw.pl/index.php/pl/wydawnictwa/polish-journal-ofecology

Kwon HK, Oh SJ, Yang HS (2013) Growth and uptake kinetics of nitrate and phosphate by benthic microalgae for phytoremediation of eutrophic coastal sediments. Bioresour Technol 129:387-395. https://doi.org/10. 1016/j.biortech.2012.11.078

Landolt E, Kandeler R (1987) The family of Lemnaceae-a monographic study: phytochemistry, physiology, application, and bibliography (vol 2 of monograph). In: Biosystematic investigations in the family of duckweeds (Lemnaceae), vol 4, no 95. Publications of the Geobotanical Institute of the ETH. Stiftung Rubel, Zurich

Mohedano RA, Costa RH, Tavares FA, Belli Filho P (2012) High nutrient removal rate from swine wastes and protein biomass production by full-scale duckweed ponds. Bioresour Technol 112:98-104. https://doi.org/ 10.1016/j.biortech.2012.02.083

Musacchio A, Re V, Mas-Pla J, Sacchi E (2020) EU Nitrates Directive, from theory to practice: environmental effectiveness and influence of regional governance on its performance. Ambio 49(2):504-516. https://doi. org/10.1007/s13280-019-01197-8 
Nardelli AE, Chiozzini VG, Braga ES, Chow F (2019) Integrated multi-trophic farming system between the green seaweed Ulva lactuca, mussel, and fish: a production and bioremediation solution. J Appl Phycol 31(2):847-856. https://doi.org/10.1007/s10811-018-1581-4

Naylor RL, Goldburg RJ, Primavera JH, Kautsky N, Beveridge MC, Clay J, Folke C, Lubchenco J, Mooney H, Troell M (2000) Effect of aquaculture on world fish supplies. Nature 405(6790):1017-1024. https://doi.org/ $10.1038 / 35016500$

Ng YS, Chan DJC (2018) Phytoremediation capabilities of Spirodela polyrhiza, Salvinia molesta and Lemna sp. in synthetic wastewater: a comparative study. Int J Phytoremediat 20(12):1179-1186. https://doi.org/10. 1080/15226514.2017.1375895

Oron G, Wildschut LR, Porath D (1985) Wastewater recycling by duckweed for protein production and effluent renovation. Water Sci Technol 17(4-5):803-817

Queiroz RCS, Lôbo IP, Ribeiro VDS, Rodrigues LB, Almeida Neto JAD (2020) Assessment of autochthonous aquatic macrophytes with phytoremediation potential for dairy wastewater treatment in floating constructed wetlands. Int J Phytoremediat 22(5):518-528. https://doi.org/10.1080/15226514.2019.1686603

Reid GK, Robinson SM, Chopin TR, Mullen J, Lander T, Sawhney M, MacDonald B, Haya K, Burridge L, Page F, Ridler N, Boyne-Travis S, Sewuster J, Marvin R, Szemerda M, Powell F (2008) Recent developments and challenges for open-water, integrated multi-trophic aquaculture (IMTA) in the Bay of Fundy, Canada. Bull Aquac Assoc Can 12

Rejmánek M, Robinson GR, Rejmankova E (1989) Weed-crop competition: experimental designs and models for data analysis. Weed Sci 37(2):276-284

Ridler N, Wowchuk M, Robinson B, Barrington K, Chopin T, Robinson S, Page F, Reid G, Szemerda M, Sewuster J, Boyne-Travis S (2007) Integrated multi- trophic aquaculture (imta): a potential strategic choice for farmers. Aquac Econ Manag 11(1):99-110. https://doi.org/10.1080/13657300701202767

Roijackers R, Szabó S, Scheffer M (2004) Experimental analysis of the competition between algae and duckweed. Arch Hydrobiol 160(3):401-412. https://doi.org/10.1127/0003-9136/2004/0160-0401

Saleem M, Chakrabarti MH, Hasan DUB (2011) Electrochemical removal of nitrite in simulated aquaculture wastewater. Afr J Biotechnol 10(73):16566-16576. https://doi.org/10.5897/AJB11.102

Tacon AG (2018) Global trends in aquaculture and compound aquafeed production. Magaz World Aquacult Soc 49:33-46 http://www.aquahana.com/wp-content/uploads/2018/06/TaconWAS.pdf

Tuomisto HL (2010) Food security and protein supply: cultured meat a solution. Asp Appl Biol 102:99-104 https://www.academia.edu/722467/Food_Security_and_Protein_Supply_Cultured_meat_a_solution

Turcios AE, Papenbrock J (2014) Sustainable treatment of aquaculture effluents - what can we learn from the past for the future? Sustainability 6(2):836-856. https://doi.org/10.3390/su6020836

Valenti WC, Kimpara JM, Preto BDL, Moraes-Valenti P (2018) Indicators of sustainability to assess aquaculture systems. Ecol Indic 88:402-413. https://doi.org/10.1016/j.ecolind.2017.12.068

Verma R, Suthar S (2015) Impact of density loads on performance of duckweed bioreactor: a potential system for synchronized wastewater treatment and energy biomass production. Environ Prog Sustain Energy 34(6): 1596-1604. https://doi.org/10.1002/ep.12157

Visvanathan C, Hung NQ, Jegatheesan V (2008) Hydrogenotrophic denitrification of synthetic aquaculture wastewater using membrane bioreactor. Process Biochem 43(6):673-682. https://doi.org/10.1016/j.procbio. 2008.02.007

Walsh É, Paolacci S, Burnell G, Jansen MA (2020) The importance of the calcium-to-magnesium ratio for phytoremediation of dairy industry wastewater using the aquatic plant Lemna minor L. Int J Phytoremediat 22:1-9. https://doi.org/10.1080/15226514.2019.1707478

Wang J, Beusen AH, Liu X, Bouwman AF (2019) Aquaculture production is a large, spatially concentrated source of nutrients in Chinese freshwater and coastal seas. Environ Sci Technol 54(3):1464-1474. https:// doi.org/10.1021/acs.est.9b03340

Wei Z, You J, Wu H, Yang F, Long L, Liu Q, Huo Y, He P (2017) Bioremediation using Gracilaria lemaneiformis to manage the nitrogen and phosphorous balance in an integrated multi-trophic aquaculture system in Yantian Bay, China. Mar Pollut Bull 121(1-2):313-319. https://doi.org/10.1016/j.marpolbul.2017. 04.034

Yongpisanphop J, Babel S, Kruatrachue M, Pokethitiyook P (2017) Hydroponic screening of fast-growing tree species for lead phytoremediation potential. B Environ Contam Tox 99(4):518-523. https://doi.org/10.1007/ s00128-017-2157-8

Zhou Y, Borisjuk N (2019) Small aquatic duckweed plants with big potential for the production of valuable biomass and wastewater remediation. Int J Environ Sci Nat Res 16(4):63-66. https://doi.org/10.19080/ IJESNR.2019.16.555942

Ziegler P, Adelmann K, Zimmer S, Schmidt C, Appenroth KJ (2015) Relative in vitro growth rates of duckweeds (Lemnaceae) - the most rapidly growing higher plants. Plant Biol 17:33-41. https://doi.org/10.1111/plb. 12184 
Publisher's note Springer Nature remains neutral with regard to jurisdictional claims in published maps and institutional affiliations.

\section{Affiliations}

\section{Simona Paolacci ${ }^{1,2}$. Vlastimil Stejskal ${ }^{1,2,3}$ - Marcel A. K. Jansen ${ }^{1,2}$}

1 School of Biological, Earth and Environmental Sciences, University College Cork, Cork, Ireland

2 Environmental Research Institute, Cork, Ireland

3 Faculty of Fisheries and Protection of Waters, South Bohemian Research Center of Aquaculture and Biodiversity of Hydrocenoses, Institute of Aquaculture and Protection of Waters, University of South Bohemia in Ceske Budejovice, Na Sádkách 1780, 37005 České Budějovice, Czech Republic 